\title{
Assessment of heart rate variability parameters in the age subgroups of patients with arterial hypertension
}

\author{
Ocena parametrów zmienności rytmu serca u pacjentów z nadciśnieniem tętniczym \\ w podgrupach wyróżnionych pod względem wieku
}

Department of Cardiology and Internal Diseases, Military Institute of Medicine, Warsaw, Poland

Correspondence: Małgorzata Maciorowska, Department of Cardiology and Internal Diseases, Military Institute of Medicine, Szaserów 128, 04-141 Warsaw, Poland,

tel.: +48261816372, e-mail: mmaciorowska@wim.mil.pl

\begin{abstract}
Age is one of the main known risk factors for cardiovascular diseases. The ageing of the body and arterial hypertension are associated with progressive dysfunction of the autonomic nervous system, which may be one of the mechanisms underlying an increased cardiovascular risk. The aim of the paper was to assess heart rate variability parameters in the age subgroups of patients with arterial hypertension. The heart rate variability parameters were compared in atolal of 139 patients with untreated arterial hypertension (mean age $45.2 \pm 10.5$ years, men $-69 \%$ of the study group) in the following subgroups distinguished by age: $\geq 45$ years $(n=72)$ and $<45$ years $(n=67)$. A temporal analysis of the heart rate variability parameters in 24 -hour Holter ECG (SDNN, rMSSD, pNN50) was conducted for 24 hours, and for the day and night periods. In addition, a spectral analysis (LF, HF, TP, LF/HF ratio) was performed. The recorded values of SDNN, rMSSD, pNN50, TP as well as night-time HF were lower in the group of patients aged $\geq 45$ years compared to the younger group. The results confirm that in patients with arterial hypertension older age is associated with a shift of the autonomic balance towards sympathetic activity, which may translate into an additional increase in cardiovascular risk.
\end{abstract}

Keywords: ageing, heart rate variability, autonomic dysfunction

Streszczenie Wiek jest jednym z głównych czynników ryzyka chorób układu sercowo-naczyniowego. Zarówno starzenie się organizmu, jak i nadciśnienie tętnicze wiążą się z postępującą dysfunkcją autonomicznego układu nerwowego, co może być jednym z mechanizmów wzrostu ryzyka sercowo-naczyniowego. Celem pracy była ocena parametrów zmienności rytmu serca u chorych z nadciśnieniem tętniczym w podgrupach wyróżnionych pod względem wieku. U 139 chorych z nieleczonym nadciśnieniem tętniczym (średni wiek 45,2 \pm 10,5 roku, mężczyźni - 69\%) dokonano porównania parametrów zmienności rytmu serca w podgrupach wyróżnionych pod względem wieku: $\geq 45$ lat $(n=72)$ i $<45$ lat $(n=67)$. Przeprowadzono analizę czasową parametrów zmienności rytmu serca w 24-godzinnym EKG metodą Holtera (SDNN, rMSSD, pNN50), odpowiednio dla całej doby, dnia i nocy, oraz analizę spektralną (LF, HF, TP, stosunek LF/HF). W grupie pacjentów $\geq 45$ lat w porównaniu z osobami młodszymi zaobserwowano niższe wskaźniki SDNN, rMSSD, pNN50, TP, a także HF z okresu nocy. Uzyskane wyniki potwierdzają, że u chorych z nadciśnieniem tętniczym dojrzały wiek wiąże się z przesunięciem równowagi autonomicznej w kierunku aktywności współczulnej, co może się przekładać na dodatkowo wyższe ryzyko sercowo-naczyniowe.

Słowa kluczowe: starzenie się, zmienność rytmu serca, dysfunkcja układu autonomicznego 


\section{INTRODUCTION}

A geing is a multifactorial process characterised by gradual changes at the molecular, cellular and tissue levels. It involves multiple pathomechanisms such as oxidative stress, systemic inflammation, mitochondrial dysfunction, autophagy deregulation, telomere shortening, and metabolic disorders ${ }^{(1-4)}$. The processes listed above may be accelerated by the longterm impact of environmental factors including smoking, environmental pollution, unbalanced diet, and sedentary lifestyle, all of which may play a contributory role in ageing ${ }^{(2)}$. The effects may include a progressive deterioration of heart function and vascular remodelling, resulting in accelerated development of cardiovascular diseases which are the leading cause of mortality worldwide ${ }^{(1,3-5)}$. Ageing is accompanied by myocardial hypertrophy, left ventricular diastolic dysfunction and impaired left ventricular systolic function during exercise. These phenomena are also observed in the course of arterial hypertension $(\mathrm{AH})^{(4,6)}$. Furthermore, numerous studies indicate progressive dysfunction of the autonomic nervous system (ANS) in the elderly, which also contributes to an elevated risk of mortality from cardiovascular causes ${ }^{(7-9)}$.

The aim of the paper was to assess heart rate variability parameters as indirect markers of ANS balance in the age subgroups of patients with $\mathrm{AH}$.

\section{MATERIAL}

The analysis included the data of patients who were recruited for the statutory project with the acronym FINEPATH conducted at the Department of Cardiology and Internal Diseases, Military Institute of Medicine in Warsaw, in 2011-2014. The study enrolled a total of 144 patients with untreated AH defined as elevated blood pressure (BP) values - $\geq 140 / 90 \mathrm{~mm} \mathrm{Hg}$ - persisting for at least 3 months. The basic characteristics of the study subjects are presented in one of the authors' earlier publications ${ }^{(10)}$. It was a prospective randomised controlled trial aimed primarily at assessing a new treatment for AH patients. The exclusion criteria were as follows: 1) confirmed secondary AH; 2) confirmed chronic renal failure [estimated glomerular filtration rate eGFR $<60 \mathrm{~mL} / \mathrm{min} / 1.73 \mathrm{~m}^{2}$; calculated using the MDRD (Modification of Diet in Renal Disease) formula]; 3) other severe comorbidities (systolic heart failure, cardiomyopathies, significant cardiac arrhythmias, significant valve disease, chronic obstructive pulmonary disease, previously diagnosed diabetes mellitus, polyneuropathy, peripheral vascular diseases); 4) age $<18$ years and $>75$ years; 5) BMI (body mass index) $>40 \mathrm{~kg} / \mathrm{m}^{2}$; 6) mental conditions preventing full patient compliance; 7) non-sinus heart rhythm (including, inter alia, continuous pacing). The study protocol was approved by the Bioethics Committee at the Military Institute of Medicine in Warsaw (Approval No. 21/WIM/2011), and all participants gave their written consent to take part in the study. The project was entered in the ClinicalTrials.gov database (NCT01996085).

\section{METHODS}

\section{Medical history and physical examination}

Medical history was collected and physical examination was conducted with a special emphasis on cardiovascular risk factors including age, sex, office measurement of mean systolic blood pressure (SBP [mm Hg]) and diastolic blood pressure (DBP [mm Hg]) as well as smoking, and family history of cardiovascular diseases, BMI $\left[\mathrm{kg} / \mathrm{m}^{2}\right]$. All patients were subjected to the following evaluations: fasting glucose $[\mathrm{mg} / \mathrm{dL}]$, creatinine $[\mathrm{mg} / \mathrm{dL}]$, cholesterol high-density lipoproteins (HDL $[\mathrm{mg} / \mathrm{dL}]$ ), low-density proteins (LDL $[\mathrm{mg} / \mathrm{dL}]$ ), and triglycerides $[\mathrm{mg} / \mathrm{dL}]$ as well as eGFR (eGFR, calculated with the MDRD formula $\left.\left[\mathrm{mL} / \mathrm{min} / 1.73 \mathrm{~m}^{2}\right]\right)$.

\section{4-hour Holter ECG recording}

24-hour Holter ECG recording was performed in all patients using LifeCard CF 3-channel digital Holter recorders (Del Mar Reynolds Medical - Spacelabs Healthcare, USA), evaluating the presence of arrhythmias; minimum, average and maximum heart rate (HR); and heart rate variability (HRV). The time and frequency parameters of HRV were assessed with the aid of the Impresario Symphony Holter Analyzer system (Del Mar Reynolds Medical - Spacelabs Healthcare Ltd., UK). Preliminary analysis of the ECG record included correction of misclassified beats, elimination of artefacts, and evaluation of arrhythmias and ST-segment changes. The RR intervals between normal QRS waveforms were extracted as normal-to-normal $(\mathrm{NN})$ intervals. The RR intervals before and after additional beats were not considered. An extended analysis excluded records with $>300$ additional beats and artefacts.

\section{Temporal analysis of heart rate variability}

Automatically performed temporal analysis included HRV parameters recorded during day time (variable_day), during night time (variable_night), and over the entire 24-hour period (variable_24h). Temporal HRV analysis provides mainly quantitative data, describing the scale of variability. The assessment of total HRV was based on SDNN (standard deviation of the average of NN intervals $[\mathrm{ms}])$. The parasympathetic component of the ANS was evaluated on the basis of rMSSD (square root of the mean of the sum of the squares of differences between adjacent $\mathrm{NN}$ intervals, $[\mathrm{ms}]$ ) and pNN50 (percentage of differences between adjacent NN intervals exceeding $50 \mathrm{~ms}[\%])^{(11)}$. 


\begin{tabular}{|c|c|}
\hline Parameter & Mean \pm SD/n (\%) \\
\hline Age [years] & $45.18 \pm 10.54$ \\
\hline Age $>45$ years & $72(51.8)$ \\
\hline Men & $96(69)$ \\
\hline $\mathrm{HR}[\mathrm{L} / \mathrm{min}]$ & $73.4 \pm 10.7$ \\
\hline OSBP [mm Hg] & $141.2 \pm 13.1$ \\
\hline ODBP $[\mathrm{mm} \mathrm{Hg}]$ & $90.2 \pm 9.3$ \\
\hline MS IDF & $81(58.3)$ \\
\hline Creatinine [mg/dL] & $0.83 \pm 0.16$ \\
\hline $\mathrm{eGFR}\left[\mathrm{mL} / \mathrm{min} / 1.73 \mathrm{~m}^{2}\right]$ & $99.9 \pm 18.4$ \\
\hline Glucose $[\mathrm{mg} / \mathrm{dL}]$ & $98.6 \pm 11.2$ \\
\hline $\mathrm{HDL}[\mathrm{mg} / \mathrm{dL}]$ & $57.8 \pm 18.5$ \\
\hline LDL [mg/dL] & $144.3 \pm 34.6$ \\
\hline $\mathrm{TG}[\mathrm{mg} / \mathrm{dL}]$ & $155.2 \pm 76.8$ \\
\hline $\mathrm{BMI}\left[\mathrm{kg} / \mathrm{m}^{2}\right]$ & $29.1 \pm 4.2$ \\
\hline \multicolumn{2}{|c|}{$\begin{array}{l}\text { BMI - body mass index; eGFR - estimated glomerular filtration rate; } \\
\text { HDL - high-density lipoproteins; HR - heart rate; LDL - low-density lipoproteins; } \\
\text { MSIDF - metabolic syndrome according to the criteria of the International } \\
\text { Diabetes Foundation; ODBP - office diastolic blood pressure; OSBP - office systolic } \\
\text { blood pressure; SD - standard deviation; TG - triglycerides. }\end{array}$} \\
\hline
\end{tabular}

Tab. 1. Basic clinical data (whole group)

\begin{tabular}{|c|c|}
\hline HRV parameters & Mean $\pm S D$ \\
\hline SDNN_24h [ms] & $140.8 \pm 36.6$ \\
\hline SDNN_day [ms] & $114.4 \pm 30.0$ \\
\hline SDNN_night [ms] & $92.6 \pm 28.4$ \\
\hline rMSSD_24h [ms] & $34.6 \pm 14.3$ \\
\hline rMSSD_day [ms] & $29.7 \pm 11.7$ \\
\hline rMSSD_night [ms] & $44.4 \pm 22.0$ \\
\hline pNN50_24h [\%] & $8.6 \pm 8.0$ \\
\hline pNN50_day [\%] & $5.9 \pm 6.3$ \\
\hline pNN50_night [\%] & $15.8 \pm 14.5$ \\
\hline LF/HF_day [-] & $4.1 \pm 3.2$ \\
\hline LF/HF_night [-] & $2.5 \pm 2.3$ \\
\hline LF_day [n.u.] & $70.5 \pm 13.34$ \\
\hline LF_night [n.u.] & $58.5 \pm 18.0$ \\
\hline HF_day [n.u.] & $23.5 \pm 10.9$ \\
\hline HF_night [n.u.] & $35.3 \pm 16.8$ \\
\hline \multicolumn{2}{|c|}{$\begin{array}{l}\text { HF - high frequency; LF - low frequency; } \mathbf{n . u .} \text { - normalised units; } \\
\text { pNN50 - percentage of differences between adjacent NN intervals exceeding } \\
50 \text { ms [\%]; rMSSD - square root of the mean of the sum of the squares } \\
\text { of differences between adjacent NN intervals [ms]; SD - standard deviation; } \\
\text { SDNN - standard deviation of the average of NN intervals [ms]. }\end{array}$} \\
\hline
\end{tabular}

Tab. 2. Heart rate variability parameters (whole group)

\section{Frequency analysis}

The HRV frequency analysis was performed using the fast Fourier transform (FFT). Based on the total frequency spectrum, normalised values of the low frequency (LF) component, high frequency (HF) component, total power (TP) of the spectrum, and the LF/HF ratio were extracted for further study. A frequency analysis was performed for each hour of the 24-hour period. In the next step, the day/night average and the day/night ratio were determined. The HF component is considered to be a marker of the parasympathetic system. The LF values are affected both by the va-

\begin{tabular}{|c|c|c|c|}
\hline Parameter & $\begin{array}{c}\text { Age } \geq 45 \text { years } \\
(n=72)\end{array}$ & $\begin{array}{c}\text { Age }<45 \text { years } \\
\quad(n=67)\end{array}$ & $p$ \\
\hline Age [years] & $53.3 \pm 6.3$ & $36.5 \pm 6.5$ & 0.0000 \\
\hline $\mathrm{HR}[\mathrm{L} / \mathrm{min}]$ & $73.6 \pm 10.1$ & $73.1 \pm 38.2$ & 0.4710 \\
\hline OSBP [mm Hg] & $141.6 \pm 12.9$ & $140.8 \pm 13.4$ & 0.559 \\
\hline ODBP $[\mathrm{mm} \mathrm{Hg}]$ & $89.4 \pm 8.9$ & $91.1 \pm 9.7$ & 0.396 \\
\hline SDNN_24h [ms] & $133.4 \pm 33.6$ & $148.8 \pm 38.2$ & 0.013 \\
\hline SDNN_day [ms] & $109.8 \pm 28.6$ & $119.4 \pm 30.8$ & 0.031 \\
\hline SDNN_night [ms] & $86.1 \pm 24.7$ & $99.5 \pm 30.6$ & 0.011 \\
\hline rMSSD_24h [ms] & $29.9 \pm 9.8$ & $39.6 \pm 16.5$ & 0.0001 \\
\hline rMSSD_day [ms] & $26.0 \pm 7.7$ & $33.7 \pm 13.8$ & 0.0003 \\
\hline rMSSD_night [ms] & $37.8 \pm 16.4$ & $51.5 \pm 25.1$ & 0.0001 \\
\hline pNN50_24h [\%] & $5.8 \pm 5.2$ & $11.5 \pm 9.4$ & $<0.0001$ \\
\hline pNN50_day [\%] & $3.8 \pm 3.6$ & $8.1 \pm 7.6$ & 0.0001 \\
\hline pNN50_night [\%] & $11.5 \pm 11.3$ & $20.5 \pm 16.2$ & 0.0001 \\
\hline LF/HF_day [-] & $4.5 \pm 3.6$ & $3.8 \pm 2.6$ & 0.228 \\
\hline LF/HF_night [-] & $2.7 \pm 2.4$ & $2.3 \pm 2.3$ & 0.105 \\
\hline LF_day [n.u.] & $70.9 \pm 13.4$ & $70.0 \pm 13.3$ & 0.721 \\
\hline LF_night [n.u.] & $59.9 \pm 18.3$ & $57.0 \pm 17.7$ & 0.280 \\
\hline HF_day[n.u.] & $21.7 \pm 9.7$ & $25.4 \pm 11.9$ & 0.108 \\
\hline HF_night [n.u.] & $32.9 \pm 16.2$ & $38.0 \pm 17.2$ & 0.046 \\
\hline TP_day $\left[\mathrm{ms}^{2}\right]$ & $2,369.6 \pm 2,098.6$ & $3,680.3 \pm 2,778.0$ & 0.0001 \\
\hline TP_night $\left[\mathrm{ms}^{2}\right]$ & $2,470.2 \pm 1,821.9$ & $3,673.1 \pm 3,100.6$ & 0.022 \\
\hline \multicolumn{4}{|c|}{$\begin{array}{l}\text { HF - high frequency; HR - heart rate; LF - low frequency; } \mathbf{n} . \mathbf{u} . \text { - normalised } \\
\text { units; ODBP - office diastolic blood pressure; OSBP - office systolic blood } \\
\text { pressure; pNN50 - percentage of differences between adjacent NN intervals } \\
\text { exceeding } 50 \mathrm{~ms} \text { [\%]; rMSSD - square root of the mean of the sum of the } \\
\text { squares of differences between adjacent NN intervals [ms]; SDNN - standard } \\
\text { deviation of the average of NN intervals [ms]; TP - total power of the } \\
\text { spectrum [ms²]. }\end{array}$} \\
\hline
\end{tabular}

Tab. 3. Comparison of HRV parameters in the age subgroups

relationships between the LF and HF components (LF/HF ratio) reflect the sympathetic-parasympathetic balance ${ }^{(11)}$.

\section{Statistical analysis}

Statistical analysis was performed using the Statistica 12.0 package (StatSoft Inc.). The distribution and normality of data were assessed visually and using the KolmogorovSmirnov test. Continuous variables were presented as means \pm standard deviation $(S D)$, and categorical variables - as absolute and relative values (percentages). The comparative analysis was performed for 2 subgroups distinguished on the basis of median age ( 45 years): $\geq 45$ years and $<45$ years. Student's $t$-test was used for variables with a normal distribution, and Mann-Whitney's $U$ test was applied for data with distribution other than normal. The Wilcoxon signedrank test was used for the evaluation of the therapeutic effect. The results were considered significant at $p<0.05$.

\section{RESULTS}

ECG Holter monitor tests were conducted in 139 patients (out of 144 patients included in the FINEPATH study) to acquire data for HRV analysis. 


\section{Basic characteristics}

Men accounted for $69 \%$ of the study group. The mean age was $45.2 \pm 10.5$ years, the mean $\mathrm{HR}-73.4 \pm 10.7 \mathrm{~L} / \mathrm{min}$, and the mean arterial pressure $-141.2 \pm 13.1 / 90.2 \pm 9.3 \mathrm{~mm} \mathrm{Hg}$. More than half $(58.3 \%)$ of the participants met the criteria of metabolic syndrome (MS) (Tabs. 1,2).

\section{Comparison of baseline HRV values}

Compared to the younger group, among patients over 45 years of age the values of the SDNN, rMSSD, pNN50 and TP parameters over the entire measurement period as well as night-time HF, were lower (Tab. 3), with comparable cardiac rhythm and blood pressure levels in both groups.

\section{DISCUSSION}

The findings of this study indicate an age-related change in the ANS activity profile in hypertensive patients. Compared to the younger group, patients aged over 45 years exhibited features of a shift of the autonomic balance towards the sympathetic nervous system. The results obtained in the HRV parameter analysis are consistent with the data reported in the literature, which, despite differences in the methodology, confirm a progressive age-related decrease in HRV parameters ${ }^{(12-17)}$. This effect is likely to add to a decrease in HRV associated with $\mathrm{AH}$ per se $^{(18-20)}$.

However, the available study findings on the additional effect of $\mathrm{AH}$ on progressive autonomic dysfunction in the elderly are not consistent. In their 2003 study, German researchers showed a statistically significant decrease in all HRV parameters assessed by 24 -hour Holter ECG recording, and their strong negative correlation with age $(p<0.001)^{(12)}$. Similar conclusions were reached by Fukusaki et al. ${ }^{(13)}$. A Brazilian study conducted in 2016 analysed a total of 1,743 patients aged 40 to 100 years, divided into 5 age groups. The study found a linear age-related decrease in SDNN, SDANN (standard deviation of the averages of $\mathrm{NN}$ intervals in 5-min segments of the entire recording) and SDNN-index (mean of the standard deviations of the averages of $\mathrm{NN}$ intervals in all 5-min segments of the entire recording). In women, the indicators were shown to be lower than in men $(p<0.001)$. The graph representing the rMSSD and pNN50 parameters was U-shaped, with the lowest point corresponding to the age bracket of 60-69 years. The lowest values for all the variables were obtained in the group of patients with noninsulin-dependent (type II) diabetes mellitus. There was no identified effect of $\mathrm{AH}$ or dyslipidaemia on the studied variables ${ }^{(14)}$. In an Indian study conducted in 2013, Abhishekh et al. assessed the effects of age and sex on the ANS regulation in a group of 189 healthy volunteers. A negative correlation was found between SDNN, rMSSD and TP, and age (SDNN: $r=-0.444, p<0.01$; rMSSD: $r=-0.552, p<0.01$; TP: $r=-0.474, p<0.01)$. Similarly, spectral analysis revealed the following parameters to be correlated with age: $\mathrm{HF}(r=-0.167, p=0.02)$ and the LF/HF ratio $(r=0.19, p<0.01)$, suggesting a relative increase in sympathetic activity with age. Moreover, multivariate analysis showed a statistically significant reduction in LF $(\beta=-6.64 ; p<0.01)$, while HF showed an upward trend $(\beta=4.47 ; p=0.053)^{(15)}$. De Andrade et al., comparing the HRV parameters in physically active, healthy individuals aged $>65$ years and their peers with $\mathrm{AH}$, showed lower HRV values in the latter group (statistical significance was achieved for the SDNN parameters: $p=0.030$ and HF: $p=0.002)^{(16)}$. In the ARIC study $(n=11,061$ participants aged 45-54 years), lower HRV in normotensive individuals $(n=7,099)$ was associated with an elevated risk of $\mathrm{AH}$ over a 9-year follow-up period ${ }^{(17)}$. However, a comparison of normotensive individuals and patients with baseline $\mathrm{AH}$ found that $\mathrm{AH}$ did not contribute to a change in HRV associated with ageing. Furthermore, the differences between the two groups were blurred. On that basis, it was concluded that the ANS was involved in the development of $\mathrm{AH}$, while differences in the autonomic profile of $\mathrm{AH}$ patients and individuals with normal blood pressure did not increase over time ${ }^{(17)}$.

Importantly, the advantages of the study included high homogeneity of the study group and the absence of significant comorbidities other than $\mathrm{AH}$. This fact reduced the potential impact of comorbidities on the relationship between the ANS and age. Another crucial aspect is the elimination of the effects of pharmacotherapy which was achieved by selecting individuals with untreated $\mathrm{AH}$ for the study.

\section{LIMITATIONS}

A limitation of the study is the small size of the study group, and hence the small size of the subgroups under analysis. Also, the findings require verification in a larger cohort, preferably in relation to healthy controls. The discussion should take into account the difficulty involved in comparing different studies because of dissimilarities in the study protocols and the duration of the analysed ECG records.

\section{CONCLUSIONS}

The results show that older age in $\mathrm{AH}$ patients is associated with a shift of the autonomic balance towards sympathetic activity, which may translate into an additional increase in cardiovascular risk.

\section{Conflict of interest}

The authors declare no conflict of interest.

\section{Sources of financing}

FINEPATH was financed from the statutory funds of the Military Institute of Medicine in Warsaw (grant no. 148/WIM). 


\section{Acknowledgements}

The authors wish to thank the team at the Department of Cardiology and Internal Diseases for their commitment to the recruitment of patients and collection of data for analysis.

\section{References}

1. de Almeida AJPO, Ribeiro TP, de Medeiros IA: Aging: molecular pathways and implications on the cardiovascular system. Oxid Med Cell Longev 2017; 2017: 7941563.

2. Constantino S, Paneni F, Cosentino F: Ageing, metabolism and cardiovascular disease. J Physiol 2016; 594: 2061-2073.

3. Chiao YA, Rabinovitch PS: The aging heart. Cold Spring Harb Perspect Med 2015; 5: a025148.

4. Lakatta EG, Levy D: Arterial and cardiac aging: major shareholders in cardiovascular disease enterprises: part II: the aging heart in health: links to heart disease. Circulation 2003; 107: 346-354.

5. Roth GA, Johnson C, Abajobir A et al.: Global, regional, and national burden of cardiovascular diseases for 10 causes, 1990 to 2015. J Am Coll Cardiol 2017; 70: 1-25.

6. Lakatta EG: So! What's aging? Is cardiovascular aging a disease? J Mol Cell Cardiol 2015; 83: 1-13.

7. Tsuji H, Larson MG, Venditti FJ et al.: Impact of reduced heart rate variability on risk for cardiac events. Circulation 1996; 94: 2850-2855.

8. Thayer JF, Yamamoto SS, Brosschot JF: The relationship of autonomic imbalance, heart rate variability and cardiovascular disease risk factors. Int J Cardiol 2010; 141: 122-131.

9. Kleiger RE, Miller JP, Bigger JT Jr et al.: Decreased heart rate variability and its association with increased mortality after acute myocardial infarction. Am J Cardiol 1987; 59: 256-262.

10. Krzesiński P, Gielerak G, Stanczyk A et al.: The effect of hemodynamically-guided hypotensive therapy in one-year observa- tion: randomized, prospective and controlled trial (FINEPATH study). Cardiol J 2016; 23: 132-140.

11. Heart rate variability. Standards of measurement, physiological interpretation, and clinical use. Task Force of the European Society of Cardiology and the North American Society of Pacing and Electrophysiology. Eur Heart J 1996; 17: 354-381.

12. Bonnemeier H, Richardt G, Potratz J: Circadian profile of cardiac autonomic nervous modulation in healthy subjects: differing effects of aging and gender on heart rate variability. J Cardiovasc Electrophysiol 2003; 14: 791-799.

13. Fukusaki C, Kawakubo K, Yamamoto Y: Assessment of the primary effect of aging on heart rate variability in humans. Clin Auton Res 2000; 10: 123-130.

14. Almeida-Santos MA, Barreto-Filho JA, Oliveira JML et al.: Aging, heart rate variability and patterns of autonomic regulation of the heart. Arch Gerontol Geriatr 2016; 63: 1-8.

15. Abhishekh HA, Nisarga $P$, Kisan R et al.: Influence of age and gender on autonomic regulation of heart. J Clin Monit Comput 2013; 27: 259-264.

16. de Andrade PE, do Amaral JAT, da Silva Paiva L et al.: Reduction of heart rate variability in hypertensive elderly. Blood Press 2017; 26: $350-358$.

17. Schroeder EB, Liao D, Chambless LE: Hypertension, blood pressure, and heart rate variability: the Atherosclerosis Risk in Communities (ARIC) study. Hypertension 2003; 42: 1106-1111.

18. Kilit C, Paşali Kilit T, Onrat E: Autonomic modulation in hypertension without hypertrophy. Acta Cardiol 2015; 70: 721-727.

19. Lucini D, Mela GS, Malliani A et al.: Impairment in cardiac autonomic regulation preceding arterial hypertension in humans: insights from spectral analysis of beat-by-beat cardiovascular variability. Circulation 2002; 106: 2673-2679.

20. Huikuri HV, Ylitalo A, Pikkujämsä SM et al.: Heart rate variability in systemic hypertension. Am J Cardiol 1996; 77: 1073-1077. 